Conjugated Linoleic Acid 급여기간과 첨가수준이 저장기간 중

\author{
육계의 부위별 품질특성에 미치는 영향 \\ 문성실* . 신철우** . 주선태** . 박구부** \\ 충남동물자원센터, 건양대학교*, 경상대학교 동물자원과학부**
}

\title{
Effects of Dietary Conjugated Linoleic Acid Levels and Periods on Meat Quality in Breast and Thigh Muscles of Broiler
}

\author{
Sung Sil Moon*, Chul Woo Shin**, Seon Tea Joo** and Gu Boo Park** \\ The Chungnam-Animal Science Center*, \\ Division of Animal Science, Gyeongsang National University**
}

\begin{abstract}
A total of 180 Arbor Acre broilers (35 days of age) were fed a diet containing $0 \%, 0.6 \%, 1.2 \%, 1.8 \%$, $2.4 \%$ or $4.8 \%$ conjugated linoleic acid (CLA) for 3 weeks then slaughtered at week 1, 2 and 3 . Thigh and breast muscles were seamed out, vaccum-packed prior to storage in a chill for days 7 to analyse thiobarbituric acid reactive substances (TBARS). The accumulation of CLA in breast and thigh muscles was increased significantly $(\mathrm{P}<0.05)$ as the CLA level was increased, but no significant difference amongst the treatments. The contents of saturated fatty acids were significantly increased $(\mathrm{P}<0.05)$ with an increase of dietary CLA level, but those of unsaturated fatty acids were significantly decreased $(\mathrm{P}<0.05)$. The content of mono unsaturated fatty acid (MUFA) was decreased as dietary CLA level increased, even though that of poly unsaturated fatty acid (PUFA) had a little difference between dietary CLA level. Dietary CLA reduced the degree of lipid oxidation in raw chicken meat during storage.
\end{abstract}

(Key words: Conjugated linoleic acid (CLA), Broiler, TBARS, Fatty acid, Lipid oxidation)

$$
\text { I. 서 론 }
$$

국내 육류유통은 국민들의 삶의 질 및 소비 자 의식수준 향상으로 많은 변화를 가져왔고, 현재에도 소비자들은 끓임없는 육류 소비형태 의 변화를 요구하고 있다. 그 중의 하나가 건강 지향형 웰빙(well-being) 육류의 섭취에 대한 것 이다. 이러한 소비형태의 변화는 유럽과 미국을 포함한 세계적인 흐름으로, 고기의 섭취와 건강 을 동시에 만족하기 위한 소비자들의 강한 욕 구에 힘입어 더욱 더 가속화 될 것이다.
일반적으로 기능성 물질은 식품성분이 가진 생체방어, 신체리듬의 조절, 질병의 방지와 회 복, 노화의 억제 등에 관계하는 신체조절기능 을 충분히 발휘하도록 하는 식품을 말하는 것 이다. 현재까지 축육에 이용되고 있는 기능성 소재로는 오메가 3 계열 지방산(EPA, DHA), lysozyme 및 tocoperol 등이 상업적으로 이용되 고 있지만, 기능성 물질의 안정성과 효과적인 면에서 만족스러운 수준에 도달하지 못하고 있 는 실정이다. 다기능성 지질 신소재로 알려진 CLA는 항암 효과(Ha 등, 1987; 1990; Belury,

Corresponding author: Gu Boo Park, Division of Animal Science and Technology, College of Agriculture and Life Science, Gyeongsang National University, Jinju, Gyeongnam 660-701, Korea. Tel: 82-55-751-5515, Fax: 82-55-752-9866, E-mail: gbpark@gsnu.ac.kr. 
1995), 면역증강효과(Cook 등, 1993; Miller 등, 1994), 콜레스테롤 저하효과(Ha와 Kim, 1994; Nicolosi 등, 1997), 체지방 감소효과(Park 등, 1997) 및 항산화 효과(Yurawecz 등, 1995) 등이 이미 입증되었고, 최근에는 가축용 사료 첨가제 및 식품 첨가물로써의 CLA 이용 가능성에 관 한 연구들이 활발하게 진행되고 있다. 축육의 CLA 이용성에 관한 연구(Du 등, 2000; 2002) 결과는 돈육, 육계 및 계란에서 기능성 물질로 써의 이용 가능성을 제시하였고, 단위동물인 육 계에 CLA를 급여할 때 콜레스테롤 감소 효과 (이 등, 1999; $\mathrm{Ha}$ 와 $\mathrm{Kim}, 1994$ ), 불포화 지방산 감소 효과(이 등, 1999), 항산화 효과(Dormandy 등, 1987) 및 육색 안정성 효과(Du 등, 2000)가 있다고 보고하였다. 그러나 사료내 CLA 첨가시 체내 축적량과 육계의 부위별 품질을 극대화할 수 있는 최적의 급여기간 및 첨가수준에 대한 연구는 아직도 미흡한 실정이다. 따라서 본 연 구는 후기 육계용 사료 내 지질 함량 $5 \%$ 에 대 한 일정량의 $\mathrm{CLA}$ 를 첨가하여 부위별로 급여기 간과 첨가수준에 따른 CLA 축적량, 지방산 조 성 및 지방산패도에 미치는 효과를 알아보기 위해 수행하였다.

\section{ㅍ. 재료 및 방법}

\section{1. 공시 동물 및 급여사료}

(1) 공시동물 및 사양조건

본 연구에 이용된 실험동물은 $\mathrm{H}$ 종계장에서 동일한 사양조건(35일령)에서 사육된 육계(Arbor Acre Broiler) 180 수를 후기 육계용 사료(K사 사 료)를 구입하여 사료내 지질 함량 비율(5\%)에 대하여 각 처리구당 $0 \%, 0.6 \%, 1.2 \%, 2.4 \%, 3.6 \%$ 및 $4.8 \%$ 의 CLA를 첨가하여 3 주 동안 급여하였다. 사료의 영향성분은 CP $18 \%$, Methionine $0.43 \%$ 및 $\mathrm{ME} 3,050 \mathrm{kcal} / \mathrm{kg}$ 으로 이루어졌다. 사육이 종료 된 육계는 1주마다 60 수씩(2 kg 내외)을 상업용 도계장에서 절두법으로 도계하였다. 그리고 각 처리구에서 10 수씩을 선별하여 대퇴부위와 가슴부위를 발골하여 표피를 완전히 제거한 후 CLA 축적량 및 지방산 조성 변화를 분석
하였으며, 지방산패도(Thiobarbituric acid reactive substances, TBARS)를 위해 샘플을 $4^{\circ} \mathrm{C}$ 의 냉장 온도에서 $1,3,5$ 및 7 일 동안 저장하면서 분석 하였다.

(2) 사료내 지질원에 대한 CLA 첨가 비율 후기 육계용 사료의 지질 함량이 $5 \%$ 로 계산 되었으며, 사료내 지질 함량 $5 \%$ 를 100 으로 기 준을 설정하여, 순도 $56 \%$ 의 $\mathrm{CLA}$ 를 처리구당 $0 \%, 0.6(0.34) \%, 1.2(0.67) \%, 1.8(1.01) \%, 2.4(1.34) \%$, 4.8(2.69)\%으로 계산하여 후기 육계사료 내에 $\mathrm{CLA}$ 를 첨가하여 혼합한 후 처리구마다 사료를 급여하였다.

\section{CLA 합성}

CLA 합성은 Ha 등(1987)의 방법으로 원형 플라스크(3l)에 ethylene glycol을 $1 \ell$ 넣은 후 질소 충진하에 $190^{\circ} \mathrm{C}$ 까지 가열한 후 10 분간 방 치시켰다. 가열이 끝난 후 $165^{\circ} \mathrm{C}$ 까지 식힌 다음 $250 \mathrm{~g} \mathrm{KOH}$ 를 첨가하고 질소 충진하에 $180^{\circ} \mathrm{C}$ 까지 재 가열을 실시한 후 $180^{\circ} \mathrm{C}$ 에서 10 분간 유지시켰다. CLA 합성의 주원료인 잇꽃유를 $500 \mathrm{ml}$ 넣고 매 30 분마다 교반하면서 6시간 동 안 이성화 작업을 실시한 후 methanol $1 \ell$ 를 첨가하였다. 그 다음 isomerized solution $500 \mathrm{ml}$, $6 \mathrm{~N} \mathrm{HCl} 250 \mathrm{ml}$, hexane $500 \mathrm{ml}$ 를 첨가하였다. 세척은 $250 \mathrm{ml}$ 증류수를 이용하여 5회 실시하 고 sodium sulfate anhydrous를 여과지 위에 넣 고 여과시킨 후 진공상태에서 용매를 회수하여 $56 \%$ 순도의 유리 CLA를 합성하였다(CLA 조성 : c9, t11-CLA 47.5\%, t10, c12-CLA 47.5\%).

\section{3. 실험방법}

(1) CLA 및 지방산 조성

CLA 및 지방산 조성은 Folch 등(1957)의 방 법으로 지방을 추출한 후 gas chromatography로 측정하였다. 세절육 $10 \mathrm{~g}$ 을 $250 \mathrm{ml}$ 삼각 플라스 크에 넣고 혼합 용액(chloroform : methanol = 2:1) $150 \mathrm{ml}$ 를 첨가한 다음 $12,500 \mathrm{rpm}$ 에서 3 분간 균 질화하여 원심분리관 $(500 \mathrm{ml})$ 에 여과(Whattman 
No, 1)한 후 $0.88 \% \mathrm{NaOH}$ 를 총 여액의 $1 / 4$ 정 도 첨가하여 균형을 맞춘 후 원심분리기(Union $5 \mathrm{KR}$, Made in Korea; 3,000 rpm, $10 \mathrm{~min}$ )를 이용 하여 원심분리하고 aspirator를 이용하여 연결된 모세관으로 상등액을 버리고 하층(lipid layer)을 취하였다. $250 \mathrm{ml}$ 원형 플라스크에 하층을 여과 하되 이때 $\mathrm{Na}_{2} \mathrm{SO}_{4}$ 를 이용하여 남은 수분을 흡 착 여과한 후 감압농축기(evaporator, England; $\left.55^{\circ} \mathrm{C}, 25 \mathrm{~min}\right)$ 에서 지질을 추출하였다. 지질을 추출한 후 $40^{\circ} \mathrm{C}$ 이하에서 질소가스를 계속 주입 하면서 농축하였으며, 농축된 지질은 질소가스 주입 후 파라핀 필름으로 밀봉하고 methylation 하기 전까지 냉동 $\left(-20^{\circ} \mathrm{C}\right.$ 이하 $)$ 하여 보관하였다. 순수 분리된 $0.5 \sim 1.0 \mathrm{mg}$ 의 지질을 시험관에 넣 고 $4 \% \mathrm{H}_{2} \mathrm{SO}_{4}\left(40 \mathrm{ml} \mathrm{H} \mathrm{H}_{2} \mathrm{SO}_{4} / 1000 \mathrm{ml}\right.$ methanol)용 액 $3 \mathrm{ml}$ 를 첨가하여 뚜껑을 닫은 후 항온수조 $\left(90^{\circ} \mathrm{C}\right)$ 에 20 분간 가열하여 실온에서 냉각하였 다. 시험관에 증류수 $1 \mathrm{ml}$ 와 hexane $2 \mathrm{ml}$ 을 넣 어 흔든 후 하층의 증류수를 제거하고 $\mathrm{Na}_{2} \mathrm{SO}_{4}$ 를 넣어 잔존하고 있는 수분을 완전히 제거한 후 상등액 2.5 3ul를 취하여 GC(HP $\left.6890^{+} \mathrm{GC}\right)$ 에 주입하여 지방산을 측정 하였다. 이때 사용 된 칼럼은 Allech AT-Silar capillary column (30 m $\times 0.32 \mathrm{~mm} \times 0.25 \mu \mathrm{l})$ 이며, 조건은 초기온도; 140 ${ }^{\circ} \mathrm{C}$, 최종온도; $280^{\circ} \mathrm{C}$, 주입기온도: $240^{\circ} \mathrm{C}$, 감지 기온도; $250^{\circ} \mathrm{C}$, Programming 속도는 $2{ }^{\circ} \mathrm{C} / \mathrm{min}$ 로 설정되었다. 그리고 Flame Ionization Detector를 사용했으며, 헬륨가스를 이용하여 flow 속도를 $50 \mathrm{ml} / \mathrm{min}$ 에서 Split ratio 100 : 1로 측정하였 다.

\section{(2) 지방산패도(Thiobarbituric acid reactive substances, TBARS)}

TBARS 측정은 Burge 등(1978)의 방법을 변 형하여 수행하였다. 시료 $5 \mathrm{~g}$ 에 BHT $50 \mu \mathrm{l}$ 와 증 류수 $15 \mathrm{ml}$ 을 가해 $14,000 \mathrm{rpm}$ 에서 30 초간 균질 화시킨 후 균질액 $1 \mathrm{ml}$ 을 시험관에 넣고 여기에 $2 \mathrm{ml} \mathrm{TBA} / \mathrm{TCA}$ 혼합용액을 넣어 완전히 혼합한 다음 $90^{\circ} \mathrm{C}$ 항온수조에서 15 분간 열처리한 후 10 분간 냉각시켜 $3,000 \mathrm{rpm}$ 에서 10 분간 원심분 리 시켰다. 원심분리 한 샘플의 상층을 회수하 여 $531 \mathrm{~nm}$ 에서 흡광도를 측정하여 계산하였다.
지방산패도 $(\mathrm{MA} \mathrm{mg} / \mathrm{kg})$ = 흡광도 $\times 5.88$

\section{4. 통계분석}

실험에서 얻어진 성적은 SAS/PC (SAS, 1998) 을 이용하여 분산분석을 실시하였으며 Tukey의 다중검정법으로 $5 \%$ 수준에서 각 요인간의 유 의성을 검정하였다.

\section{III. 결과 및 고찰}

\section{CLA 첨가수준과 급여기간이 CLA 축적율 에 미치는 영향}

CLA 첨가수준 $(0.6 \%, \quad 1.2 \%, 2.4 \%, 3.6 \%$ 및 4.8\%)에 따른 사료를 육계에 3주 동안 급여하 였을 때 가슴부위의 CLA 축적률의 결과를 Fig. 1 에 나타내었다. CLA를 첨가하지 않은 대조구 의 경우 사양기간에 관계없이 $\mathrm{CLA}$ 의 축적이 전혀 일어나지 않았다. Hughes 등(1982)은 단위 동물의 경우 자체적으로 체내에서 CLA 합성이 이루어지지 않고 체내 CLA 축적을 위해서는 외부적인 공급이 필요하다고 보고하였다. 각각 의 급여기간에서 CLA 첨가수준이 증가할수록

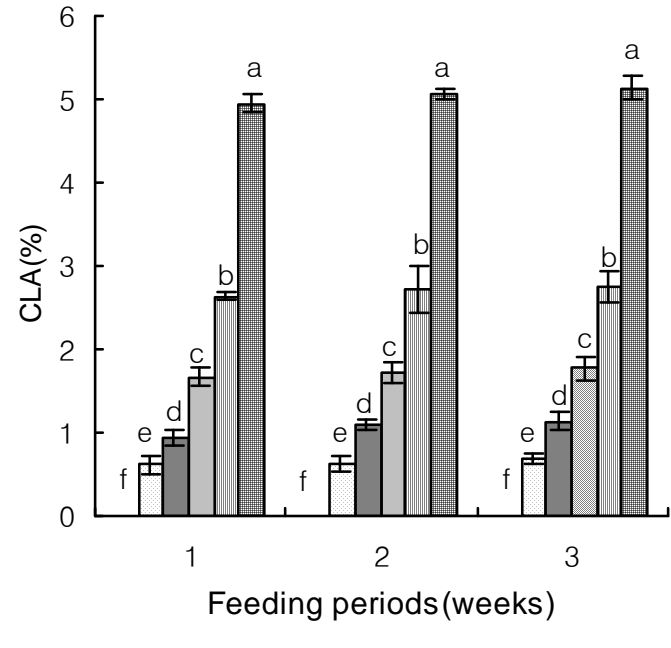

$\square 0 \% \square 0.6 \% \square 1.2 \% \square 2.4 \% \square 3.6 \% \square$ 4.8\% CLA

Fig. 1. Influence of dietary conjugated linoleic acid level and feeding period on CLA accumulation in broiler breast meat. 
$\mathrm{CLA}$ 의 축적율은 유의적으로 $(\mathrm{p}<0.05)$ 증가하였 다. 급여기간에 따른 각 처리구들의 CLA 축적 률은 $0.6 \% \mathrm{CLA}$ 첨가구가 급여 1 주에서 $0.67 \%$, 2주에서 $0.71 \%$, 3주에서 $0.76 \%$ 로 급여기간이 증가함에 따라 증가하는 경향을 보였지만, 증 가폭은 높지 않은 것으로 나타났다. $1.2 \%$ CLA 첨가구는 급여 1 주, 2주, 3주에서 각각 $1.13 \%$, $1.18 \%, 1.40 \%$ 의 CLA 축적률을 보였고, $2.4 \%$ CLA 첨가구는 $2.21 \%, 2.27 \%, 2.44 \%$ 를 나타내 었다. 그리고 $3.6 \%$ CLA 첨가구의 경우 $3.18 \%$, $3.19 \%, 3.47 \%$ 를 $4.8 \%$ CLA 첨가구는 $5.18 \%$, $5.25 \%, 5.53 \%$ 의 축적율을 보였으며, 이는 CLA 첨가수준이 증가함에 따라 대퇴근육내 CLA 축 적률이 뚜렷하게 증가했음을 나타낸다. 그러나 각 처리구에서 급여기간에 따른 축적률의 변화 는 급여 1주와 급여 2주 및 3주간에 미미한 것 으로 나타났다. 이러한 결과는 가슴근육에 대 한 측정치의 결과에서도 동일하였는데(Fig. 2), 박 등(1999)은 단위가축에 일정량의 CLA를 장 기간 급여하면 어느 시점에서 CLA 축적이 최대 로 이루어지고 더 이상의 축적은 일어나지 않는 다고 보고하였는데, 이는 체내에서 세포막 흡수 가능량이 일정량 이상일 경우에는 세포막의 유 동성을 유지하기 위해 과량으로 흡수된 CLA는 체내대사에 이용되기 때문이라고 보고하였다. 이상의 결과에서, 육계 사양을 위한 경제성을 고려할 때, 근육내 CLA 축적을 위한 최적의 급 여기간 1 주가 적합할 것으로 사료된다.

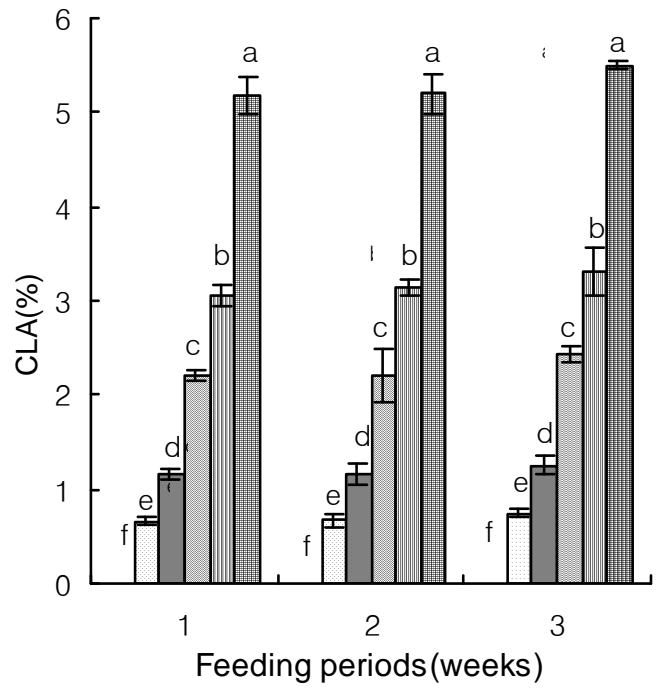

$\square 0 \% \square 0.6 \% \square 1.2 \% \square 2.4 \% \square 3.6 \% \square 4.8 \%$ CLA

Fig. 2. Influence of dietary conjugated linoleic acid level and feeding period on CLA accumulation in thigh muscle of broiler.

\section{2. $\mathrm{CLA}$ 첨가수준이 근육내 지방산의 조성 변화에 미치는 영향}

CLA 급여 1주에서 CLA 첨가수준에 따른 대 퇴와 가슴부위의 지방산 조성 결과를 Table 1 과 2에 나타내었다. 본 실험의 결과에서 지방 산 중 가장 많은 양을 차지하고 있는 oleic $\operatorname{acid}(\mathrm{C} 18: 1)$ 는 CLA 첨가수준이 증가할수록 유

Table 1. The effect of dietary CLA level on fatty acid profile in breast muscle

\begin{tabular}{|c|c|c|c|c|c|c|c|}
\hline$\underbrace{\text { CLA(\%) }}_{\text {Fatty } \operatorname{acid}(\%)}$ & 0 & 0.6 & 1.2 & 2.4 & 3.6 & 4.8 & S.E.M \\
\hline $14: 00$ & $0.95^{\mathrm{d}}$ & $1.01^{\mathrm{cd}}$ & $1.02^{\mathrm{C}}$ & $1.05^{\mathrm{b}}$ & $1.06^{\mathrm{b}}$ & $1.19^{\mathrm{a}}$ & $\begin{array}{l}0.01 \\
\end{array}$ \\
\hline $16: 00$ & $25.54^{\mathrm{e}}$ & $26.79^{\mathrm{d}}$ & $27.52^{\mathrm{cd}}$ & $27.76^{\mathrm{c}}$ & $28.22^{\mathrm{b}}$ & $29.25^{\mathrm{a}}$ & 0.24 \\
\hline 16:01 & $7.76^{\mathrm{a}}$ & $7.49^{\mathrm{b}}$ & $6.86^{\mathrm{C}}$ & $6.38^{\mathrm{d}}$ & $6.01^{\mathrm{e}}$ & $4.76^{f}$ & 0.15 \\
\hline 18:00 & $6.33^{\mathrm{d}}$ & $6.74^{\mathrm{cd}}$ & $7.12^{\text {bcd }}$ & $7.47^{\mathrm{b}}$ & $8.18^{\mathrm{ab}}$ & $9.06^{\mathrm{a}}$ & 0.67 \\
\hline 18:01 & $42.58^{\mathrm{a}}$ & $41.57^{\mathrm{b}}$ & $41.09^{\mathrm{bc}}$ & $40.66^{\mathrm{c}}$ & $39.89^{\mathrm{d}}$ & $37.76^{\mathrm{e}}$ & 0.28 \\
\hline 18:02 & $16.44^{\mathrm{a}}$ & $15.78^{\mathrm{ab}}$ & $15.45^{\mathrm{b}}$ & $15.01^{\mathrm{c}}$ & $14.01^{\mathrm{d}}$ & $13.07^{e}$ & 0.22 \\
\hline CLA & $0.00^{f}$ & $0.62^{\mathrm{e}}$ & $0.94^{\mathrm{d}}$ & $1.66^{\mathrm{C}}$ & $2.64^{\mathrm{b}}$ & $4.95^{\mathrm{a}}$ & 0.05 \\
\hline 20:04 & $0.39^{\mathrm{e}}$ & $0.00^{\mathrm{b}}$ & $0.00^{\mathrm{b}}$ & $0.00^{\mathrm{b}}$ & $0.00^{\mathrm{b}}$ & $0.00^{\mathrm{b}}$ & 0.001 \\
\hline MUFA & 50.34 & 49.06 & 47.95 & 47.04 & 45.89 & 42.52 & \\
\hline PUFA & 16.83 & 16.40 & 16.39 & 16.68 & 16.65 & 18.02 & \\
\hline
\end{tabular}


Table 2. The effect of dietary CLA level on fatty acid profile in thigh muscle

\begin{tabular}{|c|c|c|c|c|c|c|c|}
\hline $\begin{array}{r}\text { CLA(\%) } \\
\text { Fatty acid(\%) }\end{array}$ & 0 & 0.6 & 1.2 & 2.4 & 3.6 & 4.8 & S.E.M \\
\hline $14: 00$ & $0.90^{\mathrm{e}}$ & $0.98^{\mathrm{d}}$ & $1.02^{\mathrm{cd}}$ & $1.08^{\mathrm{C}}$ & $1.18^{\mathrm{b}}$ & $1.29^{\mathrm{a}}$ & "0.02 \\
\hline $16: 00$ & $24.54^{f}$ & $25.09^{\mathrm{e}}$ & $26.24^{\mathrm{d}}$ & $27.66^{\mathrm{c}}$ & $28.41^{\mathrm{b}}$ & $29.34^{\mathrm{a}}$ & 0.19 \\
\hline $16: 01$ & $8.10^{\mathrm{a}}$ & $7.76^{\mathrm{b}}$ & $7.44^{\mathrm{C}}$ & $7.01^{\mathrm{cd}}$ & $6.54^{\mathrm{d}}$ & $6.20^{\mathrm{e}}$ & 0.18 \\
\hline $18: 00$ & $6.43^{c}$ & $7.12^{\mathrm{bc}}$ & $7.32^{\mathrm{b}}$ & $7.38^{\mathrm{b}}$ & $8.29^{\mathrm{ab}}$ & $9.00^{\mathrm{a}}$ & 0.45 \\
\hline 18:01 & $43.18^{\mathrm{a}}$ & $42.47^{\mathrm{b}}$ & $41.03^{c}$ & $40.04^{\mathrm{d}}$ & $38.80^{\mathrm{e}}$ & $36.62^{f}$ & 0.22 \\
\hline 18:02 & $16.41^{\mathrm{a}}$ & $15.91^{\mathrm{b}}$ & $15.81^{\mathrm{bc}}$ & $14.98^{\mathrm{C}}$ & $13.74^{\mathrm{d}}$ & $12.39^{\mathrm{e}}$ & 0.25 \\
\hline CLA & $0.00^{\mathrm{f}}$ & $0.66^{\mathrm{e}}$ & $1.15^{\mathrm{d}}$ & $2.21^{\mathrm{c}}$ & $3.05^{\mathrm{b}}$ & $5.18^{\mathrm{a}}$ & 0.03 \\
\hline 20:04 & $0.44^{\mathrm{a}}$ & $0.00^{\mathrm{b}}$ & $0.00^{\mathrm{b}}$ & $0.00^{\mathrm{b}}$ & $0.00^{\mathrm{b}}$ & $0.00^{\mathrm{b}}$ & 0.001 \\
\hline MUFA & 51.28 & 50.23 & 48.47 & 47.05 & 45.34 & 42.82 & \\
\hline PUFA & 16.85 & 16.57 & 16.96 & 17.19 & 16.79 & 17.57 & \\
\hline
\end{tabular}

의적으로 $(\mathrm{P}<0.05)$ 감소하는 경향을 나타내었으 며, linoleic acid(C18:2)와 palmitoleic acid(C16:1) 도 비슷한 결과를 보였다. Ahn 등(1999)과 $\mathrm{Du}$ 등(1999)은 CLA를 급여할 경우 육계의 근육조 직이나 난황지질의 oleic acid의 함량이 감소한 것을 관찰하였는데, 이는 stearyl-CoA 탈포화효 소의 발현 감소와 관련이 있기 때문이라고 보 고하였다. 불포화 지방산과 달리 myristic acid (C14:0), palmitic acid(C16:0), stearic acid(C18:0) 와 같은 포화지방산은 CLA 첨가수준이 증가할 수록 유의적으로 $(\mathrm{P}<0.05)$ 증가하는 경향을 보였 는데, 이는 CLA에 의한 $\Delta^{9}$ 탈포화 효소의 활 성 저해와 관련된 것으로 palmitic $\operatorname{acid}(\mathrm{C} 16: 0)$ 나 stearic acid(C18:0)와 같은 포화지방산이 oleic $\operatorname{acid}(\mathrm{C} 18: 1)$ 등과 같은 불포화지방산으로의 합 성율이 저하되었기 때문인 것으로 사료된다. $\mathrm{Du}$ 등(1999)은 stearic acid(C18:0)와 magaric acid (C17:0) 함량이 CLA 급여수준이 증가한 만큼 증가하기 때문에 불포화지방산의 농도가 감소 한다고 보고하여 본 실험의 결과를 뒷받침하였 다. 또한 본 연구는 CLA 급여가 근육에서의 불포화 지방산의 함량을 낮추는 효과가 있으며 (Du 등, 2001a, b), arachidonic acid, linoleic acid 그리고 oleic acid 함량을 낮추고 전체 지방산 조성에서 포화지방산을 증가시킨다는 보고(Du 등, 2002; Joo 등, 2002)와도 일치하는 결과를 보였다. 지방산의 구조식이 CLA와 가장 비슷 한 linoleic aicd(C18:2)는 CLA 함량이 증가할수
록 감소하는 경향을 나타내었는데, 이는 Ha 등 (1989), Chin 등(1992, 1994) 및 $\operatorname{Lin}$ 등(1995)의 연구에서 CLA 함량이 증가할수록 linoleic acid 가 감소하였다는 보고와 일치하는 경향이었으 며, 그 이유는 비슷한 구조식으로 인해 세포막 에서 CLA가 linoleic acid(C18:2)로 대체될 수 있는 가능성이 높기 때문에 CLA의 함량이 증 가할수록 linoleic acid(C18:2)의 함량이 감소하 는 것과 관련된 것으로 사료된다.

\section{CLA 첨가수준이 저장기간중 육계의 지방 산패도에 미치는 영향}

CLA 첨가수준을 달리하여 육계 사료를 1 주 간 급여했을 경우 저장기간에 따른 지방산패도 (TBARS)의 결과(Fig. 3)는 대조구와 모든 처리 구에서 저장기간이 경과함에 따라 지방산패도 가 증가하는 경향을 보였다. 이러한 결과는 박 등(1999b)의 연구와 일치하였는데, 그들은 근육 의 저장기간이 경과할수록 근육의 TBARS 값 은 증가한다고 보고하였다. 저장 기간에 따른 비교에서, 저장 1 일에서 CLA 첨가수준에 따른 TBARS 값은 통계적인 차이가 인정되지 않았 지만, 저장 3 일째부터 CLA 축적량이 많을수록 유의적으로 $(\mathrm{p}<0.05)$ 낮은 TBARS 값을 나타내 었다. 대조구와 CLA 처리구간의 비교에서는 첨가수준이 가장 낮은 $0.6 \%$ 처리구의 경우 대 조구와 유의적인 차이는 인정되지 않았지만, 


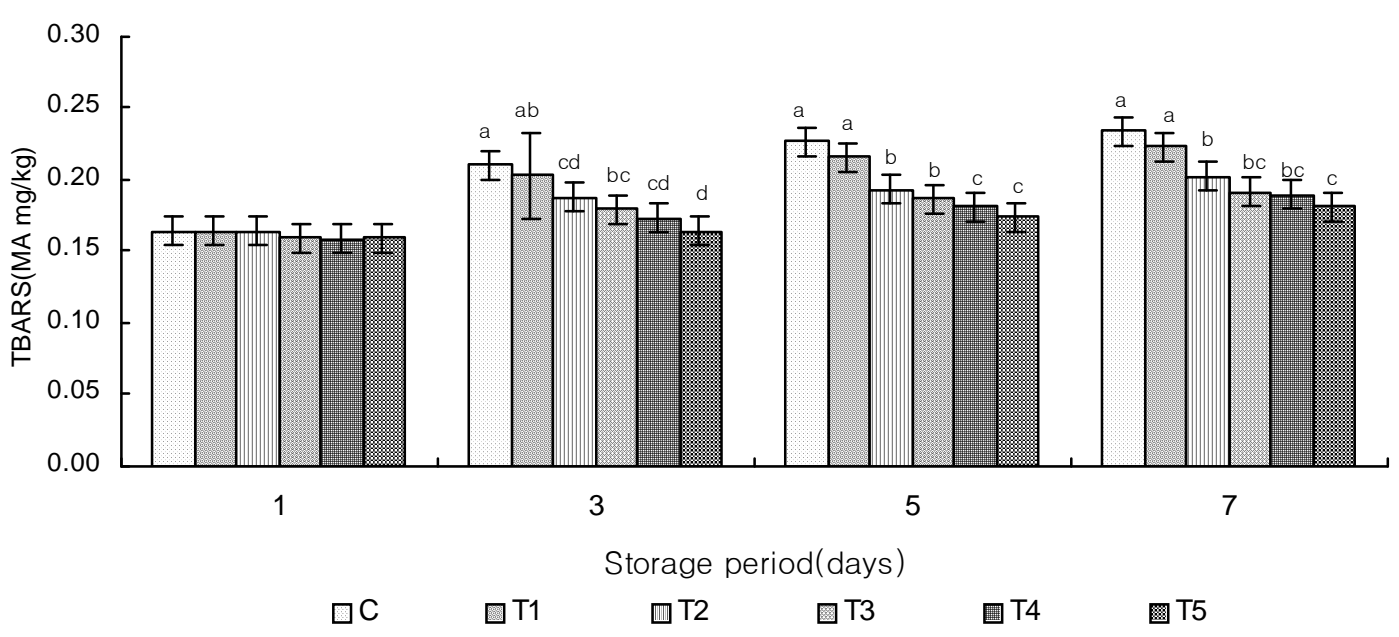

Fig. 3. Influence of dietary CLA on TBARS (MA mg/kg) in thigh muscle of broiler during storage in a chill.

첨가수준이 $1.2,2.4,3.6$ 및 $4.8 \%$ 처리구는 대 조구에 비해 유의적으로 $(\mathrm{p}<0.05)$ 낮은 TBARS 값을 나타내었다. 특히 CLA $4.8 \%$ 처리구는 $2.4 \%$ 및 $3.6 \%$ 처리구와 통계적인 차이가 없었 지만, $0.6 \%$ 및 $1.2 \%$ 에 비해서는 유의적으로 $(\mathrm{p}<0.05)$ 낮은 TBARS 값을 보였다. 저장 5일에 서는 $4.8 \%$ 처리구가 $3.6 \%$ 처리구와는 통계적인 차이가 없었지만, 다른 처리구에 비해 가장 낮 은 $(\mathrm{P}<0.05)$ TBARS 값을 보였다. 그리고 저장 7 일에서는 $4.8 \%$ 처리구가 $0.6 \%$ 및 $1.2 \%$ 처리구 에 비해 유의적으로 $(\mathrm{p}<0.05)$ 낮은 TBARS 값을 나타내었다. 또한 전체적인 저장기간에서 $4.8 \%$ 처리구는 저장 1 일에서의 대조구와 비교할 때 TBARS 값은 수치적으로 약간 상승하는 경향 을 보였지만, 큰 차이는 없는 것으로 나타났다. 이러한 결과는 CLA 첨가수준을 높임으로써, 저장 중 일어나는 지방 산화를 억제하는데 효 과가 있다는 것을 입증하는 것이다. 기작은 CLA 첨가수준이 증가함에 따라 포화지방산의 함량 증가와 불포화지방산의 함량 감소의 결과 (Table 1과 2)와 밀접하게 관련된 것으로 사료 된다. $\mathrm{Du}$ 등(2002)과 Joo 등(2002)은 CLA 급여 가 지방에서 arachidonic acid, linoleic acid 및 oleic acid 함량을 낮추고 전체 지방산 조성에서 포화지방산의 비율을 증가시킴으로써 지방 산 화를 감소시킬 수 있다고 보고하여 본 실험의
결과를 뒷받침하였다. $\mathrm{Ha}$ 등 (1991)은 CLA의 항산화 작용에 대한 가설을 두 가지로 설명하 였는데, CLA는 in vitro 상태에서 산화되면서 항산화성이 있는 구조(ß-hydroxy acrolein)로 변형 되어 transition metal을 chelation함으로써 fenton reaction을 방해하기 때문이라는 것과 CLA 분자 내에 있는 conjugate 이중결합 그 자체도 철과 같은 transition metal을 역시 chelation 하기 때 문이라고 보고하였다.

\section{IV. 요 약}

$\mathrm{CLA}$ 를 이용한 고품질 기능성 육계의 생산 가능성을 알아보기 위해 첨가수준과 급여기간 에 따른 부위별 CLA 축적율과 지방산 조성 및 지방산패도를 분석하였다. CLA 축적율은 첨가 수준이 증가할수록 유의적으로 $(\mathrm{P}<0.05)$ 증가하 였으며, 급여기간에 따라서도 다소 증가하는 경향을 보였다. 그러나 급여 1주와 급여 2주 및 3주의 비교에서 큰 차이는 나타나지 않았 다. CLA 첨가수준에 따른 포화지방산은 증가 하는 경향을 보였지만, 불포화 지방산은 감소 하는 경향을 보였으며, 특히 CLA와 가장 비슷 한 구조를 가지고 있는 linoleic acid(C18:2)는 CLA 함량이 증가한 만큼 감소하는 경향을 나 타내었다. CLA 첨가수준에 따른 지방산패도의 
변화는 첨가수준이 증가함에 따라 낮게 나타났 으며, 대조구에 비해 처리구가 낮게 나타났다. 이상의 결론은 근육내 CLA 축적을 극대화 시 키기 위한 최적의 급여기간은 1 주이며, 지방산 패도의 효과적인 억제를 위해서 첨가수준 $4.8 \%$ 가 가장 적합하다는 것을 나타낸다.

\section{$\mathrm{V}$. 인 용 문 헌}

1. Ahn, D. U., Sell, J. L., Jo, C., Chamruspollert, M. and Jeffrey, M. 1999. Effect of dietary conjugated linoleic acid on the quality characteristics of chicken eggs during refrigerated storage. Poultry Science. 78(6):922-928.

2. Belury, M. A. 1995. Conjugated dienoic linoleate: A polyunsaturated fatty acid with unique chemoprotective properties. Nutr. Rev. 53:83-89.

3. Burge, J. A. and Aust, S. D. 1978. Microsomal lipid peroxidation. Methods Enzymol. 52:302-303.

4. Chin, S. F., Liu, W., Storkson, J. M., Ha, Y. L. and Pariza, M. W. 1992. Dietary sources of conjugated dienoic isomers of linoleic acid, a newly recognized class of anticarcinogens. J. Food Comp. Anal. 5:185-197.

5. Chin, S. F., Storkson, J. M., Albright, K. J., Cook, M. E. and Pariza, M. W. 1994. Conjugated linoleic acid is a growth factor for rats as shown by enhanced weight gain and improved feed efficiency. J. Nutr. 124:2344-2349.

6. Cook, M. E., Miller, C. C., Park, Y. and Pariza, M. 1993. Immune modulation by altered nutrient metabolism: Nutritional control of immune-induced growth depression. Poultry Sci. 72:1301-1305.

7. Dormandy, T. L. and Wickens, D. G. 1987. The experimental and clinical pathology of diene conjugation. Chem Phys. Lipid. 45:353-361.

8. Du, M., Ahn, D. U. and Sell, J. L. 1999. Effect of dietary CLA on the composition of egg ylok lipids. Poultry Sci. 78:1639-1645.

9. Du, M., Ahn, D. U., Nam, K. C. and Sell, J. L. 2000. Influence of dietary conjugated linoleic acid on volatile profiles, color and lipid oxidation of irradiated raw chicken meat. Meat Sci. 56:387-395.

10. Du, M., Ahn, D. U., Nam, K. C. and Sell, J. L. 2001. Volatile profiles and lipid oxidation of irradiated cooked chicken meat from laying hens fed with diets containing conjugated linoleic acid. Poul. Sci. 80:235-241.

11. Du, M., Nam, K. C. Hur, S. J., Ismail, H. and Ahn, D. U. 2002. Effect of dietary conjugated linoleic acid, irradiation, and packaging conditions on the quality characteristics of raw broiler breast fillets. Meat. Sci. 60:9-15.

12. Du, M., Nam, K. C., Hur, S. J., Ismail, H. A, Kim, Y. H. and Ahn, D. U. 2001b. Effect of dietary conjugated linoleic acid (CLA) on the growth, fat accumulation and meat quality of broilers. Poul. Sci. In press.

13. Folch, J., Lees, M. and Sloane-Stanley, G. H. 1957. A simple method for the isolation and purification of total lipid form animal tissues. J. Biol. Chem. 226:497.

14. Ha, Y. L. and Kim, J. O. 1994. Culture tube method for the determination of total cholesterol in egg yolk lipid. J. Korean Soc. Food Nutr., 23:1032.

15. Ha, Y. L., Grimm, N. K. and Pariza, M. W. 1987. Anticarcinogens from fried ground beef: heataltered derivatives of linoleic acid. Carcinogenesis 8:1881-1887.

16. Ha, Y. L., Nancy K. Grimm and Michael W. Pariza. 1989. Newly Recognized Anticarcinogenic Fatty acids : Identification and Quantification in Natural and Processed Cheeses. J. Agric. Food Chem. 37:75-81.

17. Ha, Y. L., Storkson, J. M. and Pariza, M. W. 1990. Inhibition of benzo(a) pyrone-induced mouse forestomach neoplasia by conjugated dienoic derivatives of linoleic acid. Cancer Res. 50:10971101.

18. Ha, Y. L. and Pariza, M. W. 1991. Naturallyoccurring novel anticarcinogens: conjugated dienoic derivatives of linoleic acid (CLA). J. Kor. Soc. Food Nutr. 24(4):401-407. 
19. Hughes, P. E., Hunter, W. J. and Tove, S. B. 1982. Biohydrogenation of unsaturated fatty acids. Purification and properties of cis, 9-transoctadecadienoate reductase. J. Biol. Chem. 257:3643-3649.

20. Joo, S. T., Lee, J. I., Ha, Y. L. and Park, G. B. 2002. Effects of dietary conjugated linoleic acid on fatty acid composition, lipid oxidation, color and water-holding capacity of pork loin. J. Ani. Sci. 80: 108-112.

21. Lin, H., Boylston, T. D., Chang, M. J., Luedecke, L. O., Shultz, T. D. and Boylston, T. D. 1995. Survey of the conjugated linoleic acid contents of dairy products. J. Dairy Sci. 78:2358.

22. Miller, C. C., Park, Y., Pariza, M. W. and Cook, M. E. 1994. Feeding conjugated linoleic acid to animals partially overcomes catabolic response due to endotoxin injection. Biochem. Biophys. Res. Commun. 198:1107-1112.

23. Nicolosi, R. J., Rogers, E. J., Kritchevsky, D., Scimeca, J. A. and Huth, P. J. 1997. Dietary conjugated linoleic acid reduces plasma lipoproteins and early aortic atherosclerosis in hypercholesterolemic hamsters. Artery. 22:266-277.

24. Park, Y., Albright, K. J., Liu, W., Storkson, J. M., Cook, M. E. and Pariza, M. W. 1997. Effect of conjugated linoleic acid on body composition in mice. Lipids. 32:853-858.
25. SAS. SAS/STAT Software for pc, SAS/STAT user's guide. 1998. Statistics. SAS inst., Cary. NC.

26. Stangl, G. I. 2000. High dietary levels of a conjugated linoleic acid mixture alter hepatic glycerophospholipid class profile and cholesterolcarrying serum lipoproteins of rats. J. Nutr. Bioche. 11:184-191.

27. Yurawecz, M. P., Hood, J. K., Mossoba, M. M., Roach, J. A. and Ku, Y. 1995. Furan fatty acids determined as oxidation products of conjugated octadecadienoic acid. Lipids. 30:595-598.

28. 박구부, 이정일, 박태선, 김진형, 신택순, 강석중, 하영래, 주선태. 1999. CLA 급여가 난황의 콜레 스테롤과 CLA 함량에 미치는 효과. 한국축산학 회지. 41:65.

29. 박구부, 이정일, 하영래, 강석중, 진상근, 주선태. 1999b. 난황내 Conjugated Linoleic Acid(CLA)가 지방산조성과 지방산화에 미치는 효과. 한국축산 식품학회. 18(4):339-347.

30. 이정일, 주선태, 최병대, 하영래, 하정기, 박구부. 1999. Conjugated Linoleic Acid(CLA) 급여기간에 계육의 CLA 함량과 지방산 조성에 미치는 영향. 한국축산학회지. 41(3):375-386.

(접수일자 : 2005. 9. 15. / 채택일자 : 2006. 2. 13.) 